JPH: Jurnal Pembaharuan Hukum

Volume 8, Number 2, August 2021

\title{
THE LEGAL PROTECTION FOR TRANSPORT PASSENGERS DURING THE COVID-19 PANDEMIC
}

\author{
Retno Hadiningtyas \\ Airlangga University Surabaya \\ retno.hadiningtyas-2018@fh.unair.ac.id
}

\begin{abstract}
Transportation as a means of supporting economic development and community development and industrial growth needs to get the main attention when conditions enter the New Normal Era because Indonesia is still experiencing a high level of spread where the mode of transportation used by many people can be a medium of spreading the COVID-19 virus. The purpose of this research is to provide legal protection to passengers by the carrier as an effort to care about the safety, comfort, safety of passengers as users of transportation services that the carrier must protect by adjusting existing regulations and in its implementation required supervision from the Government and the public. This research is normative legal research that uses a legislative approach and is sourced from primary legal materials. The data was collected by studying libraries sourced from primary, secondary, and non-legal legal materials. The research results prove that the legal protection of passengers by the carrier can run well if the passengers consciously adhere to the Health Protocol and comply with government rules as a form of effort to maintain all transportation elements with all activities. So these efforts have an impact on preventing the spread of the COVID-19 virus that is increasing in Indonesia.
\end{abstract}

Keywords: Covid-19; Legal Protection; Transport; Passengers.

\section{A. INTRODUCTION}

A dangerous reality is shaking the world to coincide with the World Health Organization's March 11, 2020 statement of the new coronavirus (Covid-19) as a pandemic. ${ }^{1}$ Coronavirus outbreaks throughout 2020 continue to experience a growing number of infections as well as mortality all over the globe. ${ }^{2}$ The outbreak of Coronavirus (COVID-19) in 2019 had a major impact, including on the transport sector. The COVID-19 epidemic also has impacted almost all aspects of human life, including education, politics,

1 Catrin Sohrabi et.al., World Health Organization Declares Global Emergency: A Review of the 2019 Novel Coronavirus (COVID-19), International Journal of Surgery: Elsevier, Volume 76, 2020, page. 71-76

2 Junyi Zhang, "Transport Policymaking That Accounts for COVID-19 and Future Public Health Threats: A PASS Approach", Transport Policy: Elsevier Ltd, Volume 99, 2020, p. 405, https://doi.org/10.1016/j.tranpol.2020.09.009, Accessed 7 December 2020. 
transportation and the economy. ${ }^{3}$ There is currently no globally agreed timeframe for abolition of a pandemic. ${ }^{4}$

The government had also taken several measures, including strict regional quarantine measures modified into large-scale social restrictions (PSBB) that are local in proportion to the severity of the province, District or city, and a prohibition of activities outside the home for some people (e.g., school, office, meeting, eating out). The implementation rules for the PSBB are set out in Government Regulation (PP) No. 21 of 2020 on large-scale social restrictions. ${ }^{5}$ Moreover, The PSBB's rules are also stated in the Prez Edict Law number. 11 in determining public health emergencies issued in 2020. ${ }^{6}$ PP and Keppres were Jokowi approved on 31 March 2020.

PP and Presidential Decrees regulate the government's strategy to deal with the Covid-19 virus's spread in Indonesia. In principle, these restrictions apply only to certain activities in areas suspected of being infected with COVID-19. The objective is to prevent COVID-19 from spreading. The community may still conduct their daily activities with some restrictions. Technically, the kinds of community activities regulated by the Department of Health Regulation (PMK) No.9 of 2020 relating to PSBB guidelines, accelerating COVID-19 management includes dismissal to the educational institutions and places of work, restriction of religious activities, The limitation of public activities and the restriction of social activities. Culture, restrictions on modes of transport and restrictions on other activities specifically related to defence and security issues. The government also highlighted a distinction between PSBB and the regional quarantine, where people are not permitted to conduct activities outside the home. ${ }^{7}$

In relation to transport, the Transport Ministry (Kemenhub) has also published a number of regulations, including Regulation 41 of 2020 considering legislation with Permenhub No. 18 of 2020 relating to delivering control, preventing the spread of Covid- $19 .{ }^{8}$ In issue 41 of Permenhub 2020, the government publishes new regulations in the transportation sector. One of them is the maximum capacity limit for public transport passengers that was previously set at a maximum of 50 percent. Airplane passengers must submit a medical test result in the form of a Covid-19 free a qualification with a Negative-Non Reactive Rapid Test or PCR (Swab) test result, fill out a

3 Azizah Ratu Buana, Problematika Regulasi Ojek Online dalam Masa Pembatasan Sosial Berskala Besar Covid-19, Adalah: Buletin Hukum dan Keadilan, Volume 4, Nomor 1, 2020, page. 138.

4 Junyi Zhang, Loc.Cit.

5 Government Regulation of the Republic of Indonesia Number 21 of 2020 concerning LargeScale Social Restrictions in the Context of Accelerating Handling of Corona Virus Disease 2019 (COVID 19), https://peraturan.bpk.go.id/Home/Details/135059/pp-no-21- year-2020.

6 Presidential Decree Number 11 of 2020 concerning the Determination of the Covid-19 Public Health Emergency, file:///C:/Users/win_8/Downloads/Keppres Number 11 of 2020.pdf.

7 Muhyiddin, Covid-19, New Normal dan Perencanaan Pembangunan di Indonesia, The Indonesian Journal of Development Planning, Volume 4, Nomor 2, 2020, page. 242.

8 Regulation of the Minister of Transportation of the Republic of Indonesia Number PM 41 of 2020 concerning Amendments to Regulation of the Minister of Transportation Number 18 of 2020 concerning Transportation Control in the Context of Preventing the Spread of Corona Virus Disease 2019 (COVID-19). 
Card for electronic health monitoring (E-HAC), this is part of the government's efforts to ensure the safety and security of passengers while travelling. ${ }^{9}$

Improving the quality of transport facilities and legal protection for each and every involved party from the transport system in particular passengers as users of transport services, are very important given that human rights as consumers of transport must also be guaranteed. A legalities of transportation cannot be separated from the effectiveness of vehicle legislation itself. Transport in Indonesia is governed by Book III of a Civil Code of Engagement, then in Book II of Chapter V of the Commercial Law Code.

Operational activities for the operation of the transport performed by the driver, where there is a party that binds itself to carry out transport activities on the order of the transport contractor or carrier. Drivers are responsible for performing their tasks, safely transporting passengers to their approved destinations, which means that in the process of moving from a location to their destination, which can take place without hindrance and which passengers are in good health, are not in danger, are injured, sick or dead, so that the purpose of transport can be achieved. In reality, however, there is still a certain lack of carelessness and negligence that is harmful to some of the parties that are detrimental to passengers as service users, so that passengers do not feel safe for their safety and comfort while traveling to their destination.

Transportation is obliged to provide guarantees of safety, comfort, and safety for passengers. However, passengers are sometimes not guaranteed the right as consumers, so they suffer losses and demand equal legal protection. In this case, the users of transportation services and service providers are only bound in limited aspects. Passengers should be entitled to protection in the form of legal responsibility for the services provided accompanied by responsibility for security, comfort, and safety, especially during the COVID-19 pandemic. Nevertheless, the reality is that the current condition is very concerning due to the lack of obedience and awareness of passengers to health protocols and compliance with the rules set by the Government, as well as the lack of binding laws and regulations between passengers and carriers. Therefore, the observance of the law to realize justice, security, order, and law enforcement must run consistently without discrimination. If the goal has not been achieved, it can be interpreted that the legislation has not been able to provide legal protection, which in this study concerns the safety of transportation passengers during the pandemic. Based on the above, the author is interested in studying, understanding, and researching more deeply about legal protection for transportation passengers when causing harm to passengers during the pandemic.

9 Rezky Agustyananto, Update: Syarat Naik Pesawat yang Harus Diikuti untuk Penerbangan Domestik Selama Pandemi Covid-19, Klook Blog, 2021, Tanggal 19 Maret 2021, Artikel ini terupdate per Selasa, 9 Februari 2021, https://www.klook.com/id/blog/syarat-naik-pesawatselama-pandemi/, Accessed 20 Maret 2021. 


\section{B. RESEARCH METHODS}

The research method in this study is normative law research, which is a type of legal research whose object is the study of legal supremacy. Normative legal research examines the state's laws as a system related to a legal event that is intended to provide legal evidence as to the basis for determining whether an event is right or wrong and how it should be according to the law. The approach used is a legislative approach, namely by examining all regulations related to legal issues with this study. Data collection techniques are conducted through library studies concerning primary and secondary legal material sources and non-legal materials: the primary legal materials, namely the Civil Code, Law Number 22 of 2009. The secondary legal materials are scientific work and other legal research such as scientific articles and journals. All legal materials are collected through library research; legal materials are analyzed deductively and presented descriptively by addressing and describing as they are by the issue under presented in the research.

\section{RESULT AND DISCUSSION}

\section{Definition of Transport (Freight)}

From the etymological point of view, transportation comes from the Latin language, meaning the carrier, the means of transport or other places; and the harbor is a mode of transport. Transportation involves transporting something of one place to the other or of one area to another. This means that transport is a service provided to help people or goods to be transported from one location to the next or to businesses and to transport or transport goods and/or passengers from one location to the next. ${ }^{10}$

Transportation is a reciprocal agreement between the transporter and also the sender, in which the passenger is obligated to complete the transport of goods and/or persons from a certain location to a certain destination in a safe manner, while the sender is bound to pay the transport money. ${ }^{11}$ This definition has similarities with the previous definition, with a slight difference, namely the emphasis on the functional aspects of transport activities, namely the transportation of persons or materials from one place to the other with a view to increasing their usefulness or value. ${ }^{12}$ The purpose of transport is to transport stuff from their hometown to their destination in order to achieve and increase efficiency and benefits. Transport could be categorized as land transport (road and rail transport), ocean transportation and air transportation. ${ }^{13}$

10 Rustian Kamaluddin, Ekonomi Transportasi: Karekteristik, Teori Dan Kebijakan, Ghalia Indonesia, Jakarta, 2003, page. 14.

11 Abdulkadir Muhammad, Arti Penting dan Strategis Multimoda Pengangkutan Niaga di Indonesia dalam Perspektif Hukum Bisnis di Era Globalisasi Ekonomi, Penerbit Genta Press, Yogyakarta, 2007, page. 1.

12 Rustian Kamaluddin, Loc.Cit.

13 Ridwan Khairandy, Machsun Tabroni, Ery Arifuddin, Djohari Santoso, Pengantar Hukum Dagang Indonesia, Jilid 1, Gama Media, Yogyakarta, 1999, page. 196. 


\section{Principles of Responsibility of Carriers in the Law of Transport}

Within the framework of liability, the term responsibility can be interpreted as liability, which is a translation of aansprakelijkheid and is a specific type of legal responsibility under civil law. The position of a human being or a corporate person who is deemed to have to pay compensation or compensation after a legal event occurs is referred to as liability. ${ }^{14}$

In the Transport Act, there are three principles or principles for determining the liability of transporter, such as: (1) the principle of faultbased liability (the principle of culpability or liability based on the principle of default); (2) the principle of rebuttable presumption of liability; (3) the absolute liability principle (absence of fault principle or strict liability, principle of fundamental liability). ${ }^{15}$

First of all the responsibility principle based on error (which is fault-based or responsibility on the principle of fault), in that teaching that the determination of the concept of transportation responsibility is based on the belief that it is the injured party or the plaintiff who proves the error of the carrier. In the case of positive Indonesian law, this principle can be applied to Article 1365 BW, which is very well known as the article on anti-law acts (Onrecht Matigedaad). According to the notion of this article, it requires the performance of the elements to render an act in contravention of law liable for damages, i.e. (1) the existence of an illegal act by accused; (2) the evidence can be blamed on the defendant; and (3) any loss incurred resulting from the error. ${ }^{16}$

The meaning of an act against the law," is not an active act, but a passive act, that is, there is no action to be taken according to the law of the individual whom it's applied. Article 1365 of the BW provisions gives the plaintiff or the injured party the freedom to prove that the loss was caused by the unlawful act of the defendant. In the meantime the specific rules on the liability of carriers for the principle of clear error are laid down in the law governing each type of transport. ${ }^{17}$

The second principle, namely the principle of the provable liability presumption, is that in accordance with that principle, an accused is often held guilty unless the defendant can prove himself innocent or bring forward things that can absolve him from guilt. In this principle, It's also similar to the first principle in that the standard of evidence is overturned, Specifically, the plaintiff must demonstrate which defendant is blameless. ${ }^{18}$

14 Peter Mahmud Marzuki, Pengantar IImu Hukum, Kencana Prenada Media Group, Jakarta, 2008, page. 258.

15 Krisnadi Nasution, Penerapan Prinsip Tanggung Jawab Terhadap Penumpang Bus Umum, Mimbar Hukum, Volume 26, Nomor 1, 2014, page. 56-66.

16 Sigit Sapto Nugroho dan Hilman Syahrial Haq, Hukum Pengangkutan Indonesia: Kajian Perlindungan Hukum Terhadap Penumpang Transportasi Udara, Cetakan I, Penerbit Navida, Surakarta, 2019, page. 26.

17 Ibid., page. 26-27.

18 Ibid. 
In the Commercial Code, the concept of accountability based on the presumption can be found in Article 468, which states: 'The transport agreement guarantees the carrier to protect the safety of the goods which must be transported from the time of receipt to the delivery date. The transporter must compensate for not abandoning all or part of the products or for damage to the goods, unless the goods are damaged. ${ }^{19}$

The third principle is absolute liability (without fault or strict liability, full liability). According to this principle, that the party causing the damage in this case is always liable to the defendant whether or not there is an error or failure to recognize who is guilty or a principle of accountability which considers that the error is irrelevant to the query about whether it occurs. The carrier cannot be exempted from any liability for any reason that results in loss to passengers or the shipper. ${ }^{20}$

This principle can be stated in the sentence that the carrier is responsible for loss of any event in the operation of the transport. The absolute liability principle is not regulated under transportation legislation. It cannot be regulated because carriers involved in transportation services do not have to be overloaded with risks. However it does not mean that the parties are not in a position to apply this principle in the carriage agreement, it is based on the concept of contract freedom. ${ }^{21}$

\section{Defining Passenger}

In Article 1 paragraph 25 of Act No.22 of 2009 on Highway Traffic and Transport, what is meant by passengers is a person who is in a vehicle other than a driver and a car crew. By binding itself after paying money or a public transport ticket as a counter-achievement in the transport agreement, a person is legally a passenger of a public passenger vehicle who in the venue that a loss, is due to the use of public transport as long as the passenger concerned is in the carrier, for example, boarding from starting point and descending to the point of destination. Passenger tickets are proof that someone has paid the transport costs and therefore also has the authority to claim his rights as a passenger. As a result, the passenger is a party to the transportation agreement, while the carrier is the other party. Passenger tickets are a condition of the carriage agreement but not an absolute necessity, because a lack of a traveler ticket does not mean that there is no agreement on the carriage of passengers. ${ }^{22}$

19 Sigit Sapto Nugroho, Hilman Syahrial Haq, Op.cit., page. 27.

20 Ibid., page. 28.

21 Ibid.

22 Law of the Republic of Indonesia Number 22 of 2009 concerning Road Traffic and Transportation, page. 5 


\section{A Form of Protection for Transport Passengers, which is under the transportation company's jurisdiction}

There are two issues raised in the human transport agreement, including the transport agreement: the transporter and the passenger. ${ }^{23}$ As one of the agreement's legal aspects, the airline has the rights and obligations that the contract must fulfill. While the protection of passengers is the primary obligation of the carrier itself, it is the responsibility of the airline to transport passengers or goods and to issue transport documents in return for their right to receive transport costs from passengers. ${ }^{24}$

Concerning several forms of protection guaranteed by Passengers Act No. 22 of 2009, namely Article 186, it is stated that public transport companies are obliged to transport people and goods after a transport agreement has been reached and that the passenger and the sender pay a transport fee. ${ }^{25}$ Article 191 also provides that the public transport company is liable for losses caused by all the shares of persons employed in the transport sector. ${ }^{26}$

Pursuant to Act No.22 of 2009 on Transportation and Road Traffic in Article 192, it is stated that public transport companies are liable for losses suffered by passengers who die or are injured because of transportation, unless they are caused by an event which cannot be prevented or avoided or because of the Passenger's fault. Under this Article, if a passenger submits to the carrier a claim for damages due to unsafe safety or any other matter due to negligence or negligence on the part of the airline, it is sufficient if the Passenger contends that he has suffered a loss due to transport. ${ }^{27}$ If the carrier denies this claim, the carrier must prove that there is no negligence or error of the caregiver. If it succeeds, the passenger must prove the negligence or error of the carrier. ${ }^{28}$

\section{COVID-19 Data for Indonesia}

As of 8 December 2020, as many as 586,842 cases have been confirmed in Indonesia with 18,000 deaths and, to date, 483,497 recoveries have been recorded, while globally, according to WHO, $66,422,058$ cases with $1,532,418$ deaths (CFR 2.3 per cent) in 219 Affected Countries and 180 Local Transmission Countries have been confirmed in COVID-19 as of 07 December 2020. The list of countries

23 Ni Ketut Pitri Adi Gunarti, dkk., Tanggung Jawab Pengangkut Terhadap Kerugian Pengguna Jasa Angkutan Barang Karena Kelalaian Pekerjanya Dalam Perjanjian Pengangkutan (Studi Kasus CV. Duta Dewata Transportindo), OJS Unud, 2018, page. 3.

24 Abdulkadir Muhamma, Hukum Pengangkutan Darat, Laut, Udara, PT. Cipta Bakti, Bandung, 1994, page. 176.

25 Law of the Republic of Indonesia Number 22 of 2009,Op.cit., page. 91.

26 Ibid. page. 92.

27 Purwosutjipto, H.M.N, Pengertian Pokok Hukum Dagang Indonesia 3 : Hukum Pengangkutan, Cetakan 4, Djambatan, Jakarta, 1991, page. 52.

28 I Gusti Agung Ayu Laksmi Astri dan I Dewa Made Suartha, Perlindungan Hukum Terhadap Penumpang Angkutan Umum Darat, Bagian Hukum Perdata, Fakultas Hukum Universitas Udayana, 2009, page. 4. 
infected with COVID-19 may be increased every day following the development of the data and information provided in the WHO Situation Report. $^{29}$

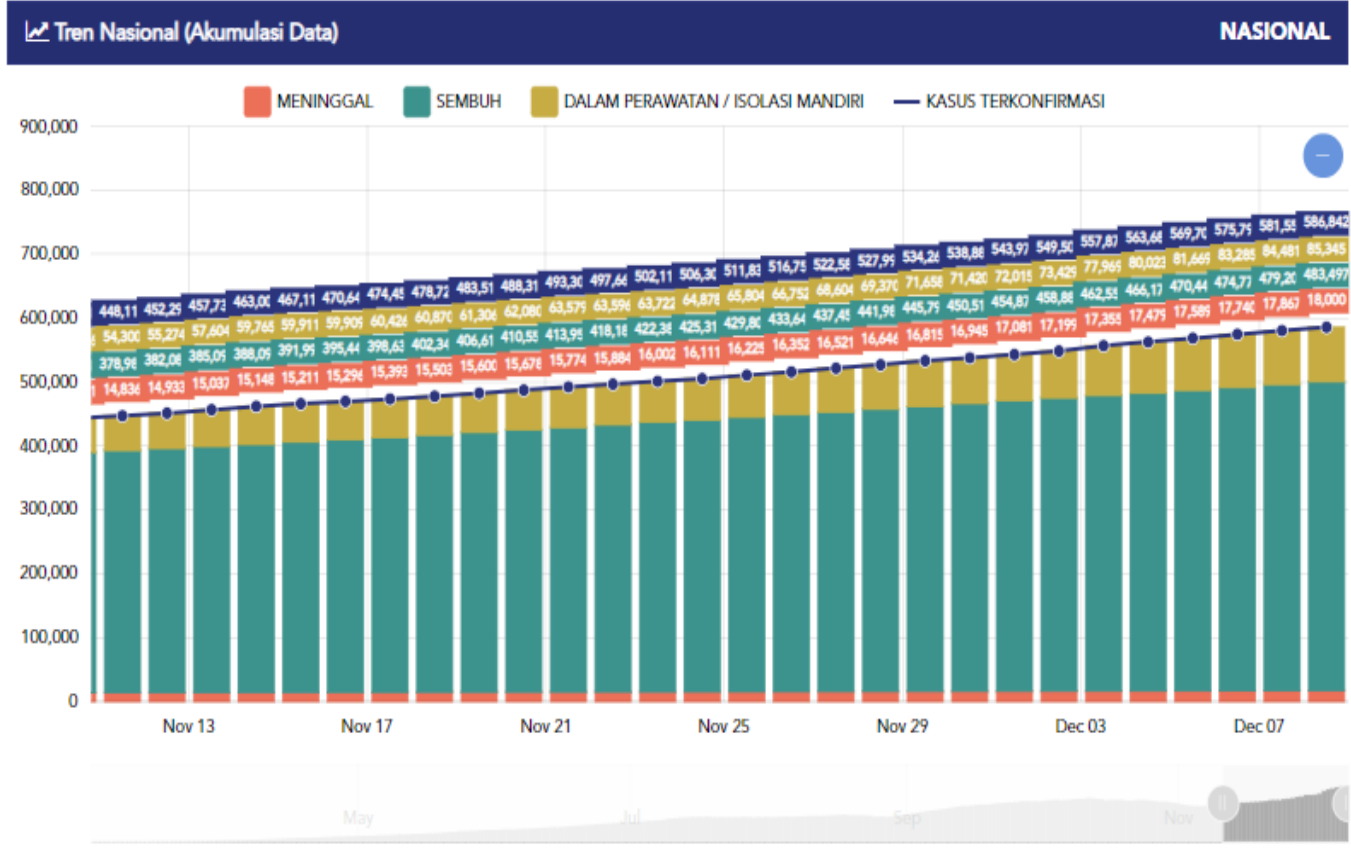

Figure 1. National Trends (Data Accumulation) ${ }^{30}$

\section{Legal Protection of Passenger Safety during the Era of Transformation for New Behaviour against COVID-19}

An increase in COVID-19 cases could be prevented if all passengers were careful to follow WHO and state instructions. If you have implemented all government-mandated health protocols and regulations, but there are unexpected or unusual events that cause infection. COVID-19 on passengers, because they are placed in a limited space with many other passengers, and social distances have to be implemented; it is no more valid the responsibility of the carrier. However, if a passenger is infected with COVID-19 while in transit due to the negligence of the page, its agent or its subcontractor, this should be the carrier's responsibility. ${ }^{31}$

In order to avoid negligence on the part of the carrier and to maintain the safety and health of passengers, the Government issued several Circular Letters as a form of legal protection for passengers by way of a Circular of the Minister of Transport, including:

29 Kemenkes RI, Situasi Terkini Perkembangan Novel Coronavirus (COVID-19), Data dilaporkan sampai

https://covid19.kemkes.go.id/download/Situasi_Terkini_050520.pdf, Accessed 07 December 2020.

30 Komisi Penanganan Covid-19 dan Pemulihan Ekonomi Nasional, Data Sebaran Covid-19, https://www.covid19.go.id/, Accessed 07 December 2020.

31 Eman Naboush et.al., Air Carrier's Liability for The Safety of Passengers during COVID-19 Pandemic, Journal of Air Transport Management: Elsevier Ltd, Volume 89, 2020, page.2 
a. Minister's Circular No. 16 of 2020 relating to amendments to Minister's Circular No. 12 of 2020 relating to the Guidelines for the Implementation of People Traveling by Sea Transportation in the Adaptation Period for New Habits towards a Productive and Safe Society of Corona Virus Disease 2019 (COVID-19). ${ }^{32}$

b. Ministerial Circular No. 14 of 2020 Concerning Guidelines and Technical Guidelines for Railway Transportation Control during the Adaptation Period for New Habits to Prevent Corona Virus Disease Disease 2019 (COVID-19). ${ }^{33}$

c. Ministerial Circular No. 13 of 2020 on Air Transportation Operations during the Productive and Safe Community Activity Period of Corona Virus Disease 2019 (COVID-19). ${ }^{34}$

d. Ministerial Circular No. 12 of 2020 on the Guidelines for the Implementation of People Traveling by Sea Transportation during the Adaptation Period of New Habits toward a Productive and Safe Corona Virus Disease Society 2019 (COVID-19). ${ }^{35}$

e. Ministerial Circular No. 11 of 2020 on Guidelines and Technical Guidelines for Land Transportation Implementation during the Adaptation Period for New Habits to Prevent Corona Virus Disease 2019 (COVID-19). ${ }^{36}$

Circular numbers $11,12,13,14,16$ of 2020 were issued following the issuance of Regulation No 41 of 2020 concerning amendments to Regulation No 18 of 2020 relating to Transportation Control in the Context of Preventing the Spread of Covid-19 and Cluster Circular Letters Task on Acceleration of Handling COVID-19. ${ }^{37}$

In each Circular on Guidelines and Implementation of People Traveling with Transportation Tools Operations during the Adaptation Period to New Habits Against the Spread of the Corona Virus 2019, for each passenger, the rules stipulate that: 1) Each passenger is responsible for his/her health by implementing the Health Protocol by covering, maintaining distance, wearing a mask, and comply with applicable regulations; (2) Each passenger must present a ticket with

32 Ministerial Circular Letter Number 16 of 2020 concerning Amendments to Circular Letter of the Minister of Transportation Number SE 12 of 2020,

33 Ministerial Circular Letter Number SE 14 of 2020 concerning Technical Guidelines for Control of Rail Transport in the Adaptation Period of New Habits to Prevent the Spread of Corona Virus Disease 2019 (COVID-19), www.dephub.go.id.

34 Ministerial Circular Letter Number SE 13 Th 2020 concerning Air Transportation Operations in the Period of Productive and Safe Community Activities from Corona Virus Disease 2019 (COVID-19),

35 Ministerial Circular Letter Number SE 12 of 2020 concerning Instructions for Traveling People by Sea Transportation in the Adaptation Period of New Habits Towards a Productive and Safe Society Corona Virus Disease 2019 (COVID-19),

36 Ministerial Circular Letter Number 11 of 2020 concerning Guidelines and Technical Guidelines for the Implementation of Land Transportation During the Adaptation of New Habits to Prevent the Spread of Corona Virus Disease 2019 (COVID-19),

37 Circular of the Task Force for the Acceleration of Handling COVID-19 Number 7 of 2020 concerning Criteria and Requirements for People's Travel in the Adaptation Period of New Habits Towards a Productive and Safe Society Corona Virus Disease (COVID-19), 
travel documents in the form of a personal identity card or other valid ID, at the time of departure, a PCR test certificate with a negative result valid for seven days or a Rapid Test Certificate with non-reactive results valid for three days, Influenza symptom-free information issued by the hospital or health center to a PCR test certificate with a negative result valid for seven days or a Rapid Test Certificate with non-reactive results valid for three days must be presented at the time of departure; Air Transport Passengers must be seated by the seat number shown on the boarding pass and are not allowed to change hearts in order to maintain physical distance on the plane and to serve food and drink.

\section{CONCLUSION}

There are two subjects in the human transport agreement, including the public transport agreement, specifically, the carrier and the passenger. Passenger protection is the primary obligation of the page itself. Several forms of protection guaranteed by Act No.22 of 2009 on Road Traffic and Passenger Transport, namely Articles 186 and 191, which provide for protection in the form of passengers and goods. Under normal circumstances, in the event of a crash, and in the incident of serious injury or death, the legal consequences for public transport companies are regulated by Act No.22 of 2009 on Transportation and vehicle traffic in Article 192 which provides that public transport companies are liable for losses suffered by passengers who die or are negatively affect as a result of transport. It is undeniably true that the concept of safety contains a meaning that is a form of personal self-protection that we know as Individual Security by complying with the Health Protocol and by complying with the implementing regulations, guidelines and instructions in order to prevent the spread of the COVID-19 virus, in addition to the fact that the carrier, in this case, must retain all the transport elements that it owns, both facilities and infrastructure, the activities of which relate to passengers and employees.

\section{BIBLIOGRAPHY}

\section{Books :}

Kamaluddin, Rustian, 2003, Ekonomi Transportasi: Karakteristik, Teori, Dan Kebijakan, Ghalia Indonesia, Jakarta;

Khairandy, Ridwan, Machsun Tabroni, Ery Arifuddin, and Djohari Santoso, 1999, Pengantar Hukum Dagang Indonesia. 1st ed, Gama Media, Yogyakarta;

Marzuki, Peter Mahmud, 2008, Pengantar IImu Hukum. Kencana.

Muhammad, Abdulkadir, 1994, Hukum Pengangkutan Darat, Laut, Dan Udara, Citra Aditya Bakti, Bandung; 
—_ 2007, Arti Penting Dan Strategis Multimoda Pengangkutan Niaga Di Indonesia Dalam Perspektif Hukum Bisnis Di Era Globalisasi Ekonomi, Penerbit Genta Press, Yogyakarta;

Nugroho, Sigit Sapto, and Hilman Syahrial Haq. 2019. Hukum Pengangkutan Indonesia: Kajian Perlindungan Hukum Terhadap Penumpang Transportasi Udara. Edited by Farkhani, Navida, Solo;

Purwosutjipto, H.M.N, 1991, Pengertian Hukum Dagang Indonesia 3: Hukum Pengangkutan, Djambatan, Jakarta;

\section{Journals :}

Astri, I Gusti Agung Ayu Laksmi, and I Dewa Made Suartha, Perlindungan Hukum Terhadap Penumpang Angkutan Umum Darat, no. 22, 2009;

Buana, Azizah Ratu, Problematika Regulasi Ojek Online Dalam Masa Pembatasan Sosial Berskala Besar Covid-19, Adalah: Buletin Hukum Dan Keadilan, Jurnal UIN Jakarta, Vol.4 No.1, 2020;

Gunarti, Ni Ketut Pitri Adi, A.A Ketut Sukranatha, and I Made Pujawan, Tanggung Jawab Pengangkut Terhadap Kerugian Pengguna Jasa Angkutan Barang Karena Kelalaian Pekerjanya Dalam Perjanjian Pengangkutan (Studi Kasus CV. Duta Dewata Transportindo, OJS Unud, 1-14, 2018;

Muhyiddin, Covid-19, New Normal Dan Perencanaan Pembangunan Di Indonesia, Jurnal Perencanaan Pembangunan: The Indonesian Journal of Development Planning, Vol.4 No.2, 2020;

Naboush, Eman, and Raed Alnimer, Air Carrier's Liability for The Safety of Passengers during COVID-19 Pandemic, Journal of Air Transport Management, Vol.89, 2020;

Nasution, Krisnadi, Penerapan Prinsip Tanggung Jawab Terhadap Penumpang Bus Umum, Mimbar Hukum, Vol.26 No.1, 2014;

Sohrabi, Catrin, Zaid Alsafi, Niamh O'Neill, Mehdi Khan, Ahmed Kerwan, Ahmed Al-Jabir, Christos Iosifidis, and Riaz Agha, World Health Organization Declares Global Emergency: A Review of The 2019 Novel Coronavirus (COVID-19), International Journal of Surgery, 76, February, 2020;

Zhang, Junyi, Transport Policymaking That Accounts for COVID-19 and Future Public Health Threats: A PASS Approach, Transport Policy, 99, 2020;

\section{Regulations:}

Indonesian Ministry of Health, 2020, Current Situation of Novel Coronavirus (COVID-19) Development, Ministry of Health. https://covid19.kemkes.go.id/download/Situasi_Terkini_050520.p df. 
Presidential Decree No. 11 of 2020 concerning the Establishment of a Covid-19 Public Health Emergency.

Regulation of the Minister of Transportation of the Republic of Indonesia Number PM 41 of 2020 concerning Amendments to Regulation of the Minister of Transportation Number 18 of 2020 concerning Transportation Control in the Context of Preventing the Spread of Corona Virus Disease 2019 (COVID-19).

Government Regulation of the Republic of Indonesia Number 21 of 2020 concerning Large-Scale Social Restrictions in the Context of Accelerating Handling of Corona Virus Disease 2019 (COVID 19). https://peraturan.bpk.go.id/Home/Details/135059/pp-no-21tahun-2020.

Circular of the Task Force for the Acceleration of Handling COVID-19 Number 7 of 2020 concerning Criteria and Requirements for People Traveling During the Adaptation of New Habits Towards a Productive and Safe Society for Corona Virus Disease (COVID-19). https://covid19.go.id/p/regulation/surat-edaran-nomor-7-tahun2020.

Ministerial Circular Letter Number 11 of 2020 concerning Guidelines and Technical Guidelines for the Implementation of Land Transportation During the Adaptation of New Habits to Prevent the Spread of Corona Virus Disease 2019 (COVID-19). http://jdih.dephub.go.id/index.php/produk_ Hukum/view/VTBVZ01URWdWRUZJVIU0Z01qQXINQT09.

Ministerial Circular Letter Number 16 of 2020 concerning Amendments to Circular Letter of the Minister of Transportation Number SE 12 of 2020. Ministry of Transportation. http://jdih.dephub.go.id/index.php/produk_ Hukum/view/VTBVZ01UWWdWRUZJVIU0Z01qQXINQT09.

Ministerial Circular Letter Number SE 12 of 2020 concerning Guidelines for the Implementation of People Traveling by Sea Transportation During the Adaptation of New Habits Towards a Productive and Safe Society Corona Virus Disease 2019 (COVID-19). http://jdih.dephub.go.id/index.php/produk Hukum/view/VTBVZ01USWdWRUZJVIU0Z01qQXINQT09.

Ministerial Circular Letter Number SE 13 Th 2020 Regarding Air Transportation Operations During Productive And Safe Community Activities From Corona Virus Disease 2019 (COVID-19), Ministry of Transportation, http://jdih.dephub.go.id/index.php/produk_ Hukum/view/VTBVZ01UTWdWRUZJVIU0Z01qQXINQT09.

Ministerial Circular Letter Number SE 14 of 2020 concerning Technical Guidelines for Control of Railway Transportation During the Adaptation of New Habits to Prevent the Spread of Corona Virus 
Disease 2019 (COVID-19), Ministry of Transportation, www.dephub.go.id.

Law of the Republic of Indonesia Number 22 of 2009 concerning Road Traffic and Transportation, http://jdih.dephub.go.id/assets/uudocs/uu/uu_no.22_tahun_2009.

Websites: pdf.

Agustyananto, Rezky, 2021, Update: Syarat Naik Pesawat Yang Harus Diikuti Untuk Penerbangan Domestik Selama Pandemi Covid-19, Klook Blog, 2021， https://www.klook.com/id/blog/syarat-naik-pesawatselama-pandemi/.

KPCPEN, 2020, Data Sebaran Covid-19, Komisi Penanganan Covid-19 dan Pemulihan Ekonomi Nasional, 2020, https://www.covid19.go.id/. 